\title{
Determinants of Sustainable Vision Strategy
}

\author{
Bhupendra Kumar Verma (Corresponding author) \\ National Institute of Industrial Engineering (NITIE) \\ Vihar Lake, Mumbai 400087, India. \\ Tel.: 91-222-803-5202Ｅ-mail: bhupihemu@ gmail.com
}

\author{
Shirish Sangle \\ National Institute of Industrial Engineering (NITIE) \\ Vihar Lake, Mumbai 400087, India \\ Tel.: 91-222-803-5202Ｅ-mail: sangle.shirish@gmail.com
}

Received: July 23, 2014 Accepted: August 5, 2014

doi:10.5296/emsd.v3i2.6007 URL: http://dx.doi.org/10.5296/emsd.v3i2.6007

\begin{abstract}
Sustainability vision strategy of a firm shall prepare a road map to the future markets, to deliver products and services in sustainable manner to compete successfully in natural resources constrained economies. This article presents important attributes of sustainable vision strategy and helps in developing a construct to measure it. A measure has been developed and tested for its validity and reliability. Further, the determinants of this strategy are identified based on a detailed empirical study of sixty Indian firms which have demonstrated some action in direction of sustainability. These firms have been chosen from several industrial sectors responsible for deteriorating the condition of the natural environment. The result shows that top management's vision of natural environment constraints and subsequent reconceptualization for unserved market based on new set of products/services and, building new alliances to penetrate unserved markets are important aspect of this strategy. Firms must explore new benchmarks of price-performance relationships to match expectations and aspirations of 'poorest of poor'. Sustainable development will likely require a collaborated effort and shared vision among stakeholders to explore, develop new markets, and then exploit them. So, firms shall initiate necessary action to develop, build and accumulate required resources to address uncertain future markets.
\end{abstract}

Keywords: Sustainable Vision, Bottom of Pyramid, Native Capability, Future Market, Natural Resources Constraints 


\section{Introduction}

Sustainable development is development that meets the needs of the present without compromising the ability of future generations to meet their own needs (WCED, 1987). It highlights two core agenda on meeting the essential needs and wants of 'poorest of poor' on priority basis and natural environments' constraints to meet not only present but also future needs of continuously growing world population.

United press release (UN press release, 2013) on population highlights that world's population will reach 8.1 billion in 2025 and 9.6 billion in 2050 and, much of this growth will be contributed by developing economies, where population will increase from 5.9 billion in 2013 to 8.2 billion in 2050 . Among countries, in 49 least developed countries, population is likely to double from around 900 million in 2013 to 1.8 billion in 2050.

Climate change report (IPCC, 2014) highlights climate change severity due to global warming and associated pollution that have caused severe negative impacts on natural and human systems of all continents. Upcoming years likely to observe crisis of water, crop yields, seasonal pattern and, will face climate-related extremes, such as heat waves, droughts, floods, cyclones, and wildfires. Such incident will have drastic negative outcomes for livelihoods, especially for people living in poverty.

Based on above reports, it can be inferred that population of poor people is growing rapidly and capacity of natural environment to absorb harmful impacts of human activities is decreasing at alarming rate. This put a question mark on agenda of sustainable development. Researchers have argued that problems of population growth, natural resources depletion and pollution are interrelated (Hart, 1997). Paul (1968) proposed that environmental burden (EB) is a function of population (P); affluence (A, a proxy for consumption) and technology (T), and can be expressed as, $\mathrm{EB}=\mathrm{P}^{*} \mathrm{~A} * \mathrm{~T}$. Observing the current situation, in which population is increasing, to achieve sustainability; affluence shall be reduced and technologies must be deployed to reduce burden on natural resources. Also, efforts shall be made to stabilize population by improving the education and economic standard of the world's poor (Hart, 1997).

Developed countries have $80 \%$ of the economic and industrial activity, despite possessing less than $20 \%$ of the world's population (Cairncross, 1991; Schmidheiny, 1992). Developed regions have achieved their status at the cost of resources depletion of developing nations. Steadily increasing population in developing countries is adding stress to already constrained natural resources of earth. The emerging economies cannot afford to repeat all the environmental mistakes of developed regions and take the same old path to delivers products and services to its significantly large customer base. If done so, the sustainable development will become an illusionary goal. In such scenario, forward looking firms must pursue strategies to reduce material and energy consumption in developed countries (Shrivastava \& Hart, 1995; Welford, 1995), and at the same time create significant economic development opportunities in developing countries in sustainable manner to address needs and wants of very large population, and continuously growing market of expectations to match their counterparts in developed nations. 
Considering the scale of development required to create economic development in sustainable manner, a long term commitment is required to develop and exploit market of future (Hart, 1995). It require a long-term vision to leverage an environmentally conscious strategy into the developing world that covers radically different low-impact environmental technology and products/services basket as the basis for market entry and growth (Schmidheiny, 1992), to address the unserved market. Successfully competing for 'markets of the future' may depend upon a firm's ability to envision sustainable technologies and products that do not yet exist to match the expectations and aspirations of large base of economically poor customer base (Hamel \& Prahalad, 1994).

Sustainability vision strategy of a firm shall prepare a road map to the future markets, to deliver products and services in sustainable manner to compete successfully in natural resources constrained economies (Hart, 1997). It essentially highlights emerging market and technological opportunities at the 'bottom of pyramid' due to population growth amid natural resources constraints which are explained in forthcoming sections.

The present study comprises a questionnaire-based survey of sixty firms located in India, which have shown some actions towards sustainability, in the last three years. The literature on environmental strategies and radical sustainable solutions in India is mostly found in sustainability / environmental reports, business articles in professional and business publications. These publications report on strategies, products, services and processes of individual firms. These publications have helped in identifying firms suitable for sampling requirement of current research work.

The outcome of this study shall guide other firms to develop necessary attributes of sustainable vision strategy at firm level to develop or implement radical sustainable solutions in better way to exploit future markets and reposition themselves strongly against the competition in natural resources constrained economies.

\subsection{Opportunities at Bottom of Pyramid}

The bottom of the pyramid (BoP) is a term that represents the 'poorest of the poor' at the base of the global socio-economic ladder, who mainly transact in an informal market economy (London, 2007). Private sector firms are continually searching for new business opportunities. The markets of developed countries are becoming more and more competitive (Hart \& Christensen, 2002). This implies that to sustain growth of past, firm must explore new markets to increase revenues and identify new sources of supply to reduce costs. This has led to greater attention on opportunities in emerging markets which are growing due to population growth and, new entrants as consumers of market at BoP (Dawar \& Chattopadhyay, 2002; Hart \& Milstein, 1999; London, 2007, Prahalad \& Lieberthal, 1998). So far, the members of BoP have not been served well and are largely ignored by firms to provide them an access to goods and services enjoyed by others at higher level of socio-economic pyramid. These traditional market failures provide potential business opportunities for sustainable growth. Firms must realize at the earliest that informal economy accounts for about 40 to 60 percent of all economic activity in developing countries (Schneider, 2004; Schneider \& Enste, 2000) and it represents the unserved needs, wants and aspirations of two third of world's population (Prahalad \& Hart, 
2002). And, the most important part is that this unserved market is growing at faster pace than any other markets of world. Researchers and global bodies have emphasized the importance of making global markets work for the poor (Narayan et al., 2000; The World Bank, 2001).

Exploring new poverty alleviation approaches and identifying ways to effectively serve the requirements of poor, and making a business case of it is the essence of future markets (Bronstein, 2004; Prahalad, 2004; Prahalad \& Hammond, 2002; Prahalad \& Hart, 2002; Yunus, 1999). Mangers must develop radically different competitive imagination and creativity to engineer a market infrastructure out of a completely unorganized, dynamic and highly turbulent informal sector (Hart \& Milstein, 2003; Prahalad \& Hart, 2002). Firms must generate wealth at the lowest levels of the pyramid first to develop purchasing power and shape aspirations for better life, and then look to leverage local solutions, and innovate simultaneously to develop exclusive products and services for bottom of pyramid (Hart \& Christensen, 2002; Simanis \& Hart, 2009). Firms must re-evaluate price performance relationships for products and services to sale them to the consumers at BoP and in this process helping the 'poorest of the poor' to improve their lives by producing and distributing products and services in culturally sensitive, environmentally sustainable, and economically profitable ways (Prahalad \& Hart, 2002).

Further, contrary to conventional investment strategies, firms must engage multiple stakeholders like local governmental authorities, nongovernmental organizations (NGOs), communities, financial institutions, and other companies (Prahalad \& Hart, 2002) and many other fringe stakeholders (Hart \& Sharma, 2004). To maintain such coalition firm must start accumulating 'organizational slack', considering the long range planning to deliver in highly uncertain market (Cyert \& March, 1963). Researchers have argued that entry into BoP markets by non-native organizations requires the development of a new capability (Hart, 2005; Hart \& London, 2005; London \& Hart, 2004; Sanchez, Ricart, \& Rodriguez, 2007). This new capability is termed as 'social embeddedness' or 'native capability' and is defined by London and Hart (2004) as 'the ability to create a web of trusted connections with a diversity of organizations and institutions, generate bottom up development, and understand, leverage, and build on the existing social infrastructure.' Rather than relying on imported solutions from the developed world, the business model of the BoP venture and any associated technological solution shall be co-created among a diversity of partners and stakeholders, with local ownership and involvement (Hart \& Sharma, 2004).

\subsection{Opportunities Due to Natural Resources Constraints}

The definition of sustainable development covers the aspects of population growth and its adverse impact on natural environment to deliver the quality of living to forthcoming generations. The research by Intergovernmental Panel on Climate Change (IPCC, 2014) clearly indicates the limited capacity of eco-system to absorb harmful outputs due to human activities.

It is estimated that about two-thirds of the world's population by 2025 will be facing moderate to severe water crisis (World Water Assessment Programme, 2006). About 5-20\% of freshwater use and $15-35 \%$ of water supply for irrigation purpose is unsustainable. Between 
years 1961 and 2007 the carbon footprint of OECD countries has increased ten times. For ASEAN countries it has increased by 100 times, for BRIC countries 20 times and for African Union countries 30 times. Melting of glaciers, shifting of precipitation patterns, intense and frequent droughts and floods are expected in the coming decades (IPCC, 2014).

Human's ecological footprint equaled earth's bio-capacity in year 1975. We, as human, have used 1.5 times of bio-capacity in year 2007 and, if similar trend continues; by year 2030 we will be needing capacity equivalent to two earths; and just over 2.8 earths each year by 2050 to satisfy same level of ecosystem services requirements and a sink to absorb harmful effects of our activities (Global Footprint Network, 2010). Over exploitation of ecosystem is leading to threats which are going to decrease the quality of eco-system and its services further. These threats are result of human demands for food, water, energy, minerals and materials. These threats have become bigger due to increase in population, higher consumption per person, lower efficiencies and effectiveness of conversion process of natural resources in usable goods and services. Very high dependency of human race on ecosystem services makes them vulnerable to the extent that future generation will be living in severe stress to maintain basic comfort which we enjoy today at almost no cost. These threats are certainly going to change the ways as business is done today.

It is clear that business need to think towards managing their natural environment constraints effectively and optimally. Businesses need to identify and understand the ecosystem services they rely upon or affected by them due to production-consumption system. They shall expand this approach to their entire value chain and its partners. They shall pursue partnerships with other companies, government agencies, regulators and civic societies to enhance integration of natural resources constraints in business operation and policy making. Business decision making shall be able to envisage future preference of customers and various stakeholders. Organizations shall develop expertise to create technological and non-technological solutions to manage ecosystem and its services. They shall devise the way to increase the efficiency and effectiveness of system to decouple the business growth from ecosystem degradation. These challenges can be converted into biggest market opportunities of all time.

\section{Research Method}

\subsection{Data Collection Instrument}

Secondary as well as primary sources of data were used for the study. Sustainability reports based on Global Reporting Initiatives (GRI) guidelines, business magazines and journals were referred for the purpose of sustainable vision strategy's dimension identification. Primary sources such as focus group discussions, in-depth interviews, observations, and survey methods were employed to identify different variables under different dimensions.

The content analysis was carried out in consultation with 25 professional and subject experts while 117 respondents were involved in the test of face validity during the pilot study. This resulted in the identification of 8 variables of this strategy around which core questions were constructed. This helped keep the questions as short as possible and to use simple, clear, concise and unambiguous language to aid the respondents' understanding. Questionnaire was 
designed using a seven-point Likert scale (1-strongly disagree to 7-strongly agree).

\subsection{Sampling and Data Collection Procedure}

The respondents were selected on the basis of stratified simple random sampling procedure. The population of the study comprising firms having implemented pollution prevention strategy. Unit of analysis is 'managers' or 'employee' of firms implementing or have adopted sustainability strategy or firms where sustainability and climate change issues may be of importance considering industry sector. For data collection, the questionnaires were mailed electronically to 1500 managers from over 150 firms in India. The cover letter that accompanied the questionnaire presented the definition and examples of pollution prevention, cleaner technology along explanation on attributes of innovative capability in order to minimize misunderstanding amongst the respondents. The generalization of the study relied on the representativeness of the respondents. Therefore, a representative selection of variety of firms belonging to different sectors including telecommunication, fast moving consumer goods (FMCG), steel, petroleum and gas, cement, automobile, textile, chemicals and paint were made. The selection included large firms with global presence and medium to small entities. The responses received were 724 (48\%) from 60 firms and questionnaires in the usable form were $689(45.9 \%)$, which is significantly higher than the usual electronic survey response rate of $35.7 \%$ (Baruch \& Holtom, 2008).

The respondents were predominantly male $(88 \%)$, aged between $32-56$ years and were the companies' authorized spokesperson on environmental issues. They were mainly from departments named as 'Corporate Sustainability Department', 'Health, Safety and Environment Department', 'Clean Development Mechanism Department', 'Marketing Department' and 'Production Department'. In initial phase, contribution of senior management in responses received was lower, so questionnaires were emailed to them separately. Also, rounds of meetings were arranged to get the responses of top management of firms. Most of the respondents possessed reasonable experience, with 35\% having more than 20 years, $40 \%$ possessing more than 15 years and the remaining $25 \%$ laid claim to more than 8 years of experience in the industry. These descriptions of respondents were voluntarily disclosed by them. The description of respondents' designations is given in Table 1.

Table 1. General Description of Respondent's Designation

\begin{tabular}{|l|c|c|}
\hline Title & Numbers & \% \\
\hline $\begin{array}{l}\text { Sustainability/Clean Development Mechanism/ Health, } \\
\text { Safety \& Environment Department, Head \& Managers }\end{array}$ & 356 & 52 \\
\hline Company Secretary & 54 & 8 \\
\hline Marketing Department, Head \& Managers & 83 & 12 \\
\hline Research \& Development, Head \& Managers & 95 & 14 \\
\hline Production Department, Head \& Managers & 101 & 15 \\
\hline
\end{tabular}

\subsection{Data Analysis}

Data analysis was carried out with SPSS version 16.0. The Kaisar Meyer Olkin (KMO) measure of sampling adequacy was applied to examine the appropriateness of factor analysis to 
test construct of measurement scales. Bartlett's test of sphericity was conducted to test the hypothesis that the variables with each dimension of a scale were uncorrelated in the population (Significance $=0.000$ ). Table 2 presents the result of KMO measure and Bartlett's test of sphericity.

Table 2. KMO and Bartlett's Test

\begin{tabular}{|l|l|r|}
\hline Kaiser-Meyer-Olkin Measure of Sampling Adequacy. & 0.813 \\
\hline Bartlett's Test of Sphericity & Approx. Chi-Square & 420.760 \\
\cline { 2 - 3 } & df & 28 \\
\cline { 2 - 3 } & Sig. & 0.000 \\
\hline
\end{tabular}

It was evident that KMO value was 0.813 , which was greater than 0.5 and Bartlett's test of sphericity supported the use of factor analysis (Significance $=0.000$ ).

Cronbach alpha coefficient has been assessed to be the most efficient measure of reliability (or internal consistency) and should be always greater than or equal to 0.7 when items are selected for testing (George \& Mallery, 2003). The Cronbach alpha value as a measure of reliability is presented in Table 3.

Table 3. Cronbach's Alpha Value of Sustainable Vision Strategy Scale

\begin{tabular}{|c|c|c|}
\hline Cronbach's Alpha & Cronbach's Alpha Based on Standardized Items & N of Items \\
\hline 0.946 & 0.948 & 8 \\
\hline
\end{tabular}

The Cronbach alpha value was found to be 0.975 , confirming that the scale was reliable.

The data obtained for sustainable vision strategy measurement scale were analysed with factor analysis with the principal component analysis (PCA) method utilizing varimax rotation with Kaiser normalization in order to reduce the information in numerous variables into a set of their weighted linear combinations. In factor analysis, only those components were considered that had eigenvalues greater than unity. The instrument was also made use of to investigate the research questions for their validity in order to assess the goodness. The designed questionnaire was subjected to construct validity (convergent and discriminant). It was confirmed that attributes loaded in excess of 0.5 with the related factor, so that they tested positive for convergent validity. It was further ensured that attributes loaded strongly on related factors than on any other factor to confirm discriminant validity. The result obtained for sustainability vision strategy measurement scale with exploratory factor analysis using PCA is presented in Table 4.

Table 4. Total Variance Explained (Extraction Method: Principal Component Analysis)

\begin{tabular}{|c|c|c|c|c|c|c|c|c|c|}
\hline \multirow{2}{*}{ Component } & \multicolumn{4}{|c|}{ Initial Eigenvalues } & \multicolumn{3}{c|}{$\begin{array}{c}\text { Extraction Sums of Squared } \\
\text { Loadings }\end{array}$} & \multicolumn{3}{c|}{$\begin{array}{c}\text { Rotation Sums of Squared } \\
\text { Loadings }\end{array}$} \\
\cline { 2 - 11 } & Total & $\begin{array}{c}\% \text { of } \\
\text { Variance }\end{array}$ & Cumulative \% & Total & $\begin{array}{c}\% \text { of } \\
\text { Variance }\end{array}$ & Cumulative \% & Total & $\begin{array}{c}\% \text { of } \\
\text { Variance }\end{array}$ & Cumulative \% \\
\hline 1 & 3.889 & 48.619 & 48.619 & 3.889 & 48.619 & 48.619 & 2.685 & 33.56 & 33.56 \\
\hline 2 & 1.256 & 15.7 & 64.318 & 1.256 & 15.7 & 64.318 & 2.461 & 30.758 & 64.318 \\
\hline
\end{tabular}

It was evident that there were two components which accounted about $64.3 \%$ of the total 
variance. Components 1 and 2 accounted approximately $33.56 \%$ and $30.76 \%$ of the total variance, respectively.

The rotated component matrix using varimax rotation method with Kaiser normalization is displayed in Table 5.

Table 5. Rotated Component Matrix: Sustainable Vision Strategy

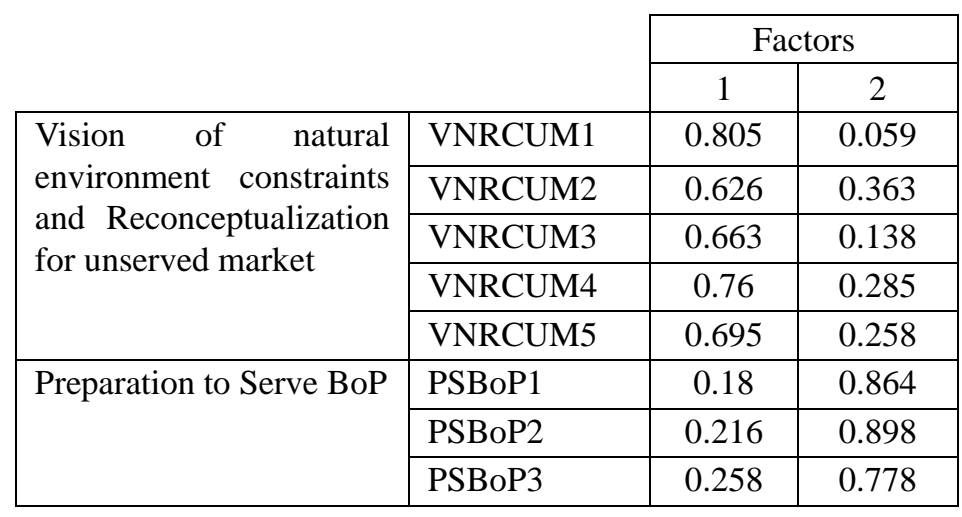

It was evident that all items have loading greater than 0.50 on their associated factors and the loading was less than 0.50 on other non-related factors. Thus measurement scale demonstrated convergent and discriminant validity.

Final structure of the sustainability vision strategy questionnaire -considering the $\%$ of total variance explained, factor loading, and eigenvalue - has been presented in Table 6.

Table 6. Final Structure of Sustainability Vision Strategy Questionnaire

\begin{tabular}{|c|c|c|c|c|}
\hline Factor & Description of Variable & $\begin{array}{l}\text { Factor } \\
\text { Loading }\end{array}$ & $\begin{array}{c}\% \text { of } \\
\text { Variance } \\
\text { explained }\end{array}$ & $\begin{array}{l}\text { Eigen } \\
\text { Value }\end{array}$ \\
\hline \multirow{5}{*}{$\begin{array}{l}\text { Vision of natural } \\
\text { environment } \\
\text { constraints and } \\
\text { Reconceptualization } \\
\text { for unserved market }\end{array}$} & $\begin{array}{l}\text { In my organization, top management has a clear } \\
\text { vision of natural environment constraints likely to } \\
\text { affect our organization (VNRCUM1) }\end{array}$ & 0.805 & \multirow{5}{*}{33.56} & \multirow{5}{*}{3.889} \\
\hline & $\begin{array}{l}\text { In my organization, there is organization wide } \\
\text { understanding that there are unmet needs \& wants of } \\
\text { weaker section of society (VNRCUM2) }\end{array}$ & 0.626 & & \\
\hline & $\begin{array}{l}\text { My organization believes that new combination of } \\
\text { products \& services will be required to address } \\
\text { population growth (VNRCUM3) }\end{array}$ & 0.663 & & \\
\hline & $\begin{array}{l}\text { My organization is re-conceptualizing its } \\
\text { products/services } \\
\text { environment/resources constraints (VNRCUM4) }\end{array}$ & 0.76 & & \\
\hline & $\begin{array}{l}\text { My organization is active in giving direction to future } \\
\text { policies on unserved market and natural resources } \\
\text { (VNRCUM5) }\end{array}$ & 0.695 & & \\
\hline \multirow[t]{2}{*}{$\begin{array}{l}\text { Preparation to Serve } \\
\text { BoP }\end{array}$} & $\begin{array}{l}\text { My organization has initiated to build } \\
\text { products/services considering the needs and wants of } \\
\text { weaker section of society (PSBoP1) }\end{array}$ & 0.864 & \multirow[t]{2}{*}{30.76} & \multirow[t]{2}{*}{1.256} \\
\hline & $\begin{array}{l}\text { My organization is building new alliances to } \\
\text { penetrate unserved markets of poor people (PSBoP2) }\end{array}$ & 0.898 & & \\
\hline
\end{tabular}




\section{Determinants of Sustainable Vision Strategy}

Based on $\%$ of the variance explained, the first factor (Vision of natural environment constraints and Reconceptualization for unserved market) can be considered relatively important than another factor (Preparation to Serve BoP). The first factors highlights that firms which were surveyed; are really considering natural resources constraints (NRC) as an important aspect in decision making for future growth. In general, top management of firms is aware that NRC may affect their future business operation (factor loading of 0.805), so they must re-conceptualize their product/service portfolio to address the NRC (factor loading of 0.76). To take advantages because of opportunities at $\mathrm{BoP}$ and depletion of natural environment, firms are proactively seeking favorable regulations and policies to commit for long-term investment (factor loading of 0.695). There is firm wide consensus that there are unserved needs, wants and aspirations of weaker section of society to be a huge growth market of future (factor loading of 0.626). And, as population grows; radically new set of products and services will be required to match the demand in economically, socially and ecologically sustainable way (factor loading of 0.663 ).

While, factor-1 deals with the competitive imagination of future markets, second factor (Preparation to Serve BoP), provides information on aspects of preparations and readiness of firms to serve the market at BoP. The firms have taken steps to develop partnership and form alliances which are required to penetrate and exploit future market (factor loading of 0.898). To match the requirements of residents at BoP, firms are developing products/services to suit their taste to match price-performance expectations (factor loading of 0.864). Considering the required presence of totally new type of value chain partners and stakeholders, firms are accumulating necessary resources to collaborate with them effectively (factor loading of 0.778).

\section{Discussion and Managerial Implications}

The growing social disparity and the unmet needs at the BoP present opportunities for firms to define a compelling trajectory for future growth (Prahalad \& Hammond, 2002). This understanding can become a catalyst for the development of innovative technologies, products, and services to meet those needs. However, the growth trajectory due to this opportunity must consider constraints posed by natural resources (Hart, 1995). Ignoring either of the aspect may not fetch goal of sustainable development. Firms must accept that there are unmet needs at BoP and natural resources constraints are detrimental to address those unserved needs. Shared vision derived from these realities is the key to generate motivation to venture into unserved markets. Accordingly, managers must re-conceptualize their product-service portfolio. While cleaner technology based solution builds on existing capability, development of sustainable products may require new set of capability and radically different mind-set. These products may be based upon existing knowledge and technology but requires passing new benchmarks of price-performance relationships. Sustainable development will likely require a collaborated effort and a long term vision between many stakeholders (who were earlier overlooked or 
ignored by firms) to explore, develop new markets, and then exploit them (Hart, 1995; Schmidheiny, 1992). It will require technology cooperation and working with host governments, local leaders and businesses to build appropriate infrastructure, develop human resources, and nurture competitiveness (Hart, 1995; Schmidheiny, 1992). Firm shall prepare to build and accumulate resources to collaborate with new set of stakeholders of future market. Sustainability vision strategy which has relatively long time horizon may open up new pathways for growth in previously un-served markets (Hart \& Christensen, 2002). The long term vision is also imperative considering longer time required to break the cycle of poverty, population growth, and natural resource depletion.

\section{Conclusion}

The key environmental challenges for India as a country is a result of complex equations due to population growth, inappropriate technology and consumption choices, poverty and economic growth leading to changes in relations between people and ecosystems. Similarly, there are many other developing countries which are facing similar challenges and are on similar growth path. However, sustainability agenda is important for all developed and developing economies so that emerging markets don't drift on path which was taken by developed economies to satisfy the needs and wants of their societies.

To understand how firms of various territories and continents can contribute to the efforts in the direction of sustainable development, this paper analyses the firms that are considered good corporate citizens and known to undertake concrete action towards the betterment of the natural environment and society. This study shall help prepare other firms (located either in developing countries or developed countries) which are yet to start on the journey of becoming a sustainable corporation. The development of a valid and reliable measurement scale to measure sustainable vision strategy shall help in assessing the performance of implementer of this strategy over the time.

Current study covers the firms from several industrial sectors like telecommunication, FMCG, steel, petroleum and gas, cement, automobile, textile, chemicals and paint, which are among the sectors chiefly responsible for the deteriorating condition of natural environment. However, to understand industry-specific determinants of this strategy, future research work can be undertaken for better insight.

\section{References}

Baruch, Y., \& Holtom, B.C. (2008). Survey response rate levels and trends in organizational research. Human Relations, 61(8), 1139-1160. http://dx.doi.org/10.1177/0018726708094863

Bronstein, D. (2004). How to change the world: Social entrepreneurs and the power of new ideas. London: Penguin Books.

Cairncross, F. (1991). Costing the earth. Boston: Harvard Business School Press.

Cyert, R. M., \& March, J. G. (1963). A Behavioral theory of the firm $\left(2^{\text {nd }}\right.$ ed.). NJ: Prentice Hall, Englewood Cliffs. 
Dawar, N., \& Chattopadhyay, A. (2002). Rethinking marketing programs for emerging markets. Long Range Planning, 35(5), 457-474. http://dx.doi.org/10.1016/S0024-6301(02)00108-5

George, D., \& Mallery, P. (2003). SPSS for Windows step by step: A simple guide and reference (11.0 update (4th ed.). Boston: Allyn \& Bacon.

Global Footprint Network. (2010). The 2010 National Footprint Accounts. Global Footprint Network, San Francisco, USA (www.footprintnetwork.org).

Hamel, G. H., \& Prahalad, C. K. (1994). Competing for the Future. Boston, MA: Harvard Business School Press.

Hart, S. (1995). A natural resource-based view of the firm. Academy of Management Review, 20, 874-907. http://dx.doi.org/10.5465/AMR.1995.9512280033

Hart, S. (1997). Beyond greening: strategies for a sustainable world. Harvard Business Review, 75(1), 66-76.

Hart, S. (2005). Capitalism at the crossroads: The unlimited business opportunities in serving the world's most difficult problems. Upper Saddle River, NJ: Wharton School Publishing.

Hart, S., \& Christensen, C. M. (2002). The great leap: Driving innovation from the base of the pyramid. Sloan Management Review, 44(1), 51-56.

Hart, S., \& London, T. (2005). Developing native capability: What multinational corporations can learn from the base of the pyramid. Stanford Social Innovation Review, 3(2), 28-33.

Hart, S., \& Milstein, M. B. (1999). Global sustainability and the creative destruction of industries. Sloan Management Review, 41(1), 23-33.

Hart, S., \& Milstein, M. B. (2003). Creating sustainable value. Academy of Management Executive, 17(2), 56-67. http://dx.doi.org/10.5465/AME.2003.10025194

Hart, S., \& Sharma, S. (2004). Engaging fringe stakeholders for competitive imagination. $\begin{array}{llll}\text { Academy of } \quad \text { Management } & \text { Executive, } & \text { 18(1), }\end{array}$ http://dx.doi.org/10.5465/AME.2004.12691227

IPCC. (2014). Climate Change 2014: Impacts, Adaptation, and Vulnerability. Working Group II Contribution to the IPCC 5th Assessment Report - Changes to the Underlying Scientific/Technical Assessment. Cambridge University Press, Cambridge, United Kingdom and New York, NY, USA.

London, T. (2007). Improving the lives of the poor? Assessing the impacts of a base-of-the-pyramid perspective. William Davidson Institute: Working paper.

London, T., \& Hart, S. (2004). Reinventing strategies for emerging markets: Beyond the transnational model. Journal of International Business Studies, 35(5), 350-370. http://dx.doi.org/10.1057/palgrave.jibs.8400099

Millennium Ecosystem Assessment, (2005). Ecosystems and Human Well-being: 
Opportunities and Challenges for Business and Industry. World Resources Institute, Washington, DC.

Narayan, D., Patel, R., Schafft, K., Rademacher, A., \& Koch-Schulte, S. (2000). Voices of the Poor: Can Anyone Hear Us? New York: Oxford University Press.

Paul, R. E. (1968). The population bomb. Sierra Club: Ballantine Books.

Prahalad, C. K. (2004). The Fortune at the bottom of the pyramid: Eradicating poverty through profits. Upper Saddle River, NJ: Wharton School Publishing.

Prahalad, C. K., \& Hammond, A. (2002). Serving the world's poor, profitably. Harvard Business Review, 80(9), 48-57.

Prahalad, C. K., \& Hart, S. (2002). The fortune at the bottom of the pyramid. Strategy+Business, 26(First Quarter), 2-14.

Prahalad, C. K., \& Lieberthal, K. (1998). The end of corporate imperialism. Harvard Business Review, 76(4), 68-79.

Sanchez, P., Ricart, J. E., \& Rodriguez, M. A. (2007). Influential factors in becoming socially embedded in low income markets. Greener Management International, 51, 19-38.

Schmidheiny, S. (1992). Changing course. Cambridge, MA: MIT Press.

Schneider, F. (2004). The size of the shadow economies of 145 countries from 1999 to 2003. Johannes Kepler University of Linz: Working paper.

Schneider, F., \& Enste, D. H. (2000). Shadow economies: Size, causes, and consequences. Journal of Economic Literature, 38(1), 77-114. http://dx.doi.org/10.1257/jel.38.1.77

Sen, A. (1999). Development as Freedom. New York: Anchor

Shrivastava, P., \& Hart, S. (1995). Creating sustainable corporations. Business Strategy and the Environment, 4, 154-165. http://dx.doi.org/10.1002/bse.3280040307

Simanis, E., \& Hart, S. (2008). The Base of the Pyramid Protocol: Toward Next Generation BoP Strategy. $\quad\left(2^{\text {nd }} \quad\right.$ ed. $) . \quad$ [Online] Available: http://www.stuartlhart.com/sites/stuartlhart.com/files/BoPProtocol2ndEdition2008_0.pdf

The World Bank. (2001). World Development Report 2000/2001: Attacking Poverty. Oxford: Oxford University Press.

UN Press Release. (2013). [Online] Available: http://esa.un.org/wpp/documentation/pdf/wpp2012_press_release.pdf

WCED. (1987). Our Common Future: World Commission on Environment and Development. Oxford University Press, Oxford.

Welford, R. (1995). Environmental strategy and sustainable development. London: Routledge. World Water Assessment Programme. (2006). Water, a shared responsibility, The United 


\section{Macrothink Institute ${ }^{\mathrm{TM}}$}

Environmental Management and Sustainable Development

ISSN 2164-7682

2014, Vol. 3, No. 2

World Water Development Report 2. [Online] Available:

http://unesdoc.unesco.org/images/0014/001444/144409e.pdf

Yunus, M. (1999). Banker to the Poor: Micro-Lending and the Battle Against World Poverty. New York: Public Affairs.

\section{Copyright Disclaimer}

Copyright for this article is retained by the author(s), with first publication rights granted to the journal.

This is an open-access article distributed under the terms and conditions of the Creative Commons Attribution license (http://creativecommons.org/licenses/by/3.0/). 